\title{
LEARNING AS PRECONDITION TO STAY ACTIVE IN LABOUR MARKET FOR ELDER PEOPLE
}

\author{
Ausra Rutkiene \\ Silva Lengviniene \\ Department of Education Sciences, Vytautas Magnus University, Lithuania
}

\begin{abstract}
Nowadays society is getting older in European countries. Technologies, speed of life requires higher level of abilities and competencies. People who are 55 and older are very experienced in their workplace but some of them cannot catch changes in their professional area. Quantitative research results demonstrate that learning is one of important factors which helps to stay active in labor market for longer time. People participate in different learning activities to get more professional competencies or to change qualification, to get higher salary or learning was required from employer. The main barriers for learning were mentioned: lack of time, no needed learning at all and lack of information. People who have longer tradition and personal motivation use different learning ways more often, and they say that learning as precondition to stay active in labor market for elder people.
\end{abstract}

Keywords: adult learning, elder people, labour market, motivation.

\section{Introduction}

Different authors and specialists differently define a limit, where the advanced age starts. The age, may be defined according to social roles in society, physical abilities and appearance (Brazienè et al., 2014, Cantwell, 2007), as well as senior citizen's health depending on his/her biologic age. However, the perception of the said age is based on an individual's subjective feeling, i.e. what age an individual feels he/she is irrespective of his/her actual years. However, based on a psychosocial human evolution theory by psychologist Erikson (1963) refers to the period of 40-65 years of age as middle adulthood, which is related to work, parenthood, whereas the period from 65 years of age is referred to as late / older adulthood (Braziene et al., 2014).

In 1983 the World Assembly on Ageing suggested a demographic criterion of ageing -60 years - as a boundary line between the middle and older age people (Koncevičiene et al., 2013). An older age criterion approved by the UN is the age of 60, whereas according to the World Health Organization's standard the age of 65 (Guidelines of the National Demographic (Population) Policy Strategy). According to Bražiūnienè, where analyzing the occupation, people from 55 years of age could be regarded as persons of older age. The unemployed precisely of this age are attributed to a group of additionally supported persons. 
This age limit is also distinguished by the European Commission, which see a 55 year old or older person as an older employee (Brazienè et al., 2014). "55 year old and older residents of Lithuania are regarded as persons of older age, except persons specified in the Descriptor of the Field of Mental Health Improvement, who are regarded as older being 45 years and older due to mental health specifics and changes [...]" ("The Action Plan for Healthy Ageing Protection in Lithuania 2014-2023”, 2014).

According Ilmarinen (2012), though, as people get older, their health usually worsens and physical capacity decreases, short-term and long-term memory important for the acquisition of new knowledge as well as ability to focus deteriorates (Charness \& Czaja, 2006), a few other functions of human body strengthen with age. Increasing intellectual competence is the advantage of an ageing person. Moreover, older employees are more devoted to their work and better in grasping the essence of work. Thus, despite various physical changes and diseases, with age older employees become better and stronger in many aspects. All of the aforementioned characteristics make older persons not only the best employees, but also enable efficiently acquiring new knowledge, improving competencies, i.e. can be very useful in the educational process.

And though, as revealed by research of Charness \& Czaja (2006), contemporary older people are active and want to be a part of social and economic life and working life has a strong influence on physical and psychological health of older people, also social and personal life of such people as well as its quality, however, based on surveys carried out in Lithuania it is often stated that older age becomes a problem in the context of social inclusion (involvement) in the labour market due to the age discrimination, health problems, as well as the lack of modern abilities of older people. The age discrimination acquires various forms in the labour market, i.e. discriminatory job ads, absence of retraining opportunities for older people, redundancy before the retirement pension. Survey carried out by Eurobarometer reveals that 50-55 year old and older persons on the labour market are forced to fight with negative stereotypes, when older persons are referred to as inefficient, inflexible, unable to adapt to innovations, and lagging behind technological progress (Eurobarometer, 2012).

The aim of this article is to discuss the motivation for older (55 years and older) persons to study in order to remain active on the labour market. Research methods - the analysis of scientific literature and questionnaire survey.

\section{Motivation for older persons to study}

Survey carried out by Statistics Lithuania in 2006 demonstrated quite high motivation of older people for work, which could be strengthened by greater 
vocational training opportunities (conditions for improving qualification), wider selection of atypical occupation forms, and adaptation of workplaces to the changed physical abilities of older people (Okunevičiūtè-Neverauskienè \& Moskvina, 2007). Older persons registered with the employment exchange is a different story. As demonstrated by the survey "Analysis of the situation of hard to integrate persons on the labour market and means for increasing their occupation", present-day's older unemployed people registered with the employment exchange are not regarded as a very big reserve, which could replenish the labour market later, in the retirement age. Trying to plan what is the chance that present-day's older unemployed people will be willing to participate on the labour market, when they have reached retirement age, almost $70 \%$ are not willing to work, when they get the retirement pension. Meanwhile one third $(30 \%)$ of older persons would be ready to continue to work even getting pension. A conclusion could be drawn that the motivation for older clients of the employment exchange to work is weak - a significant percentage wishes to end their working career as soon as possible and does not plan to be a part of the labour market in the retirement age (Okunevičiūte-Neverauskiene \& Moskvina, 2007, p. 238-239).

Adult education volumes in the country and learning efficiency first of all depend on motivation to study, therefore, it is important to assess the factors of external and internal motivation for older people to study. Motivation is characterized by two things: need (as an internal aspect of motivation) and goal (as an external aspect of motivation). Need - the main source of activity of an individual - encourages an individual's activity and search for the objects, which could satisfy him/her (Descriptor of Competencies of Expert Assessors, 2007). According to Beresnevičienè (1996), the existential and safety needs are the ones to encourage an individual to adapt in the ever-changing society and to adjust to the market requirements. Unemployment and changing requirements for a specialist force an adult to change his/her profession, to retrain, to learn or improve as a specialist at colleges or higher education institutions. On the other hand, according to the aforementioned author, as a personality develops and continually learns from own life and the life of others, such higher needs of striving for self-actualization and developing intellectual as well as creative powers form as well. This causes a need for self-expression (self-actualization). This need is recognized as a universal need of Homo sapiens, moreover, it is also a prerequisite for mental health (if not self-actualization it self, then at least a feeling of moving in this direction) (Descriptor of Competencies of Expert Assessors, 2007). Learning needs can often be subconscious, unperceived. Often a symptom of such condition is dissatisfaction with the current situation, lack of self-trust, lack of trust in own expertise, failure to see the perspective, in the worst-case scenario - a feeling of frustration (complete helplessness), also 
aggression, search for the guilty (e.g., inappropriate system, etc.). Without denying the fact that in most cases the established cultural norms (e.g., what is surmountable or not surmountable by a disabled person) or financial circumstances (e.g., in general in the state, provided or non-provided financing of professional competence improvement activities) are the essential conditions of his/her situation, which do not change an individual's will, we should not leave out the fact that sometimes an individual simply cannot envisage possibilities of changing the situation on his/her own initiative. Therefore, the dimensions brought and the intersection of dimensions of the requirements of surrounding environment are particularly important, since an individual can take a decision that nothing can be changed, that the circumstances are invincible, and choose:

- denial and related psychological, socioeconomic, and such other consequences (e.g., health deterioration) or

- exploration of his/her potential and possibilities to increase it through, for example, learning (Descriptor of Competencies of Expert Assessors, 2007).

It could be stated that the motivation for adults to study is influenced by different needs: changes in the labour market needs, internal self-realization needs of an individual, i.e. both external and internal factors. Motivating internal factors, based on the Adult Education Development Scenario (2011), are the importance of need, profundity of interests, attitude towards the object of learning and its place among the values of life, individual traits of a person. Internal motivation of an individual was emphasized by the representatives of humanistic psychology Maslow and Rogers. According to them, every single person has his/her internal "principle of growth", which navigates the behavior. According to Maslow, education has to be person-oriented, help him/her to express himself/herself and become a better person. Education also has to help $\mathrm{him} / \mathrm{her}$ to identify himself/herself, to discover his/her vocation, to learn to feel the value of life, to get the feeling of success, to learn to make a right choice. Such internal, continuously increasing motivation, which encourages independence, proactiveness, and responsibility, according to Maslow, only emerges at the highest stage of the hierarchy of needs - at self-actualization level. Motivation for learning creates a general mood for learning, whereas specific learning steps will depend on the chosen goals (Descriptor of Competencies of Expert Assessors, 2007, Butkienè \& Kepalaitè, 1996). External factors are the influence of other persons, appeal and significance of the object in an individual's personal life, surrounding geographic and social environment, as well as learning opportunities. According to the data of survey carried out by the Lithuanian Association of Adult Education, adults in Lithuania react to certain external factors of motivation (better job, promotion, higher salary, etc.), 
however, the most powerful factors are internal factors (a wish to get greater satisfaction from work, self-esteem, quality of life, etc.) (Adult Education Development Scenario, 2011). Where distinguishing and generalizing the aspects of motivation for older persons to study, it could be stated that external factors of motivation serve as significant incentive for older persons to study and improve professional and other competencies and knowledge (especially a clear understanding of the ever-changing and increasing requirements of the labour market), however, with reference to the surveys, internal factors often prevail as well: striving for improvement, broadening horizons, self-realization, communication with other persons of similar age, as well as networking. Older persons, who are already employed, earn higher income, and have higher education, are the ones to study and improve their qualification in Lithuania more often, meanwhile persons, who are unemployed and earn lower income, as well as older persons, who live in rural localities, have relatively low motivation to study. Thus, here it could be assumed that motivation can be related to not only internal and external motivating factors, but also to the availability of learning opportunities, i.e. older people, who live in rural and more secluded localities, may have a view that the education is inaccessible or hardly accessible to them, therefore, they are not motivated to even consider the opportunities for training.

\section{Empirical research methods}

Research was carried out in February of 2015. A research instrument questionnaire - was prepared on the basis of theoretical analysis and contained parts aimed at the identification of: reasons for learning (failure to study), motivation for learning, learning methods, and activity on the labour market, with reference to the instruments used by Mockus, Žukaite (2012), Tamutienè (2009), Juozulynas and others (2010), Dollisso, Martin (1999), Braziené and others (2014). Cronbach's alpha of individual parts varies from 0.784 to 0.904 .

Since it was a pilot research, it was aimed at purifying the instrument and identifying general tendencies.

Data was collected by direct survey, by explaining the purpose of research to each respondent individually and presenting the questionnaire in accordance with the principles of voluntary participation. Descriptive statistics and nonparametric criteria (chi-square criterion, Spearman's rank correlation coefficient) were applied to the analysis of research data. 


\section{Quantitative research results}

Research covered 102 respondents from Kaunas, Vilnius, and Telšiai counties, where of women -91.2 percent, men -8.8 percent.

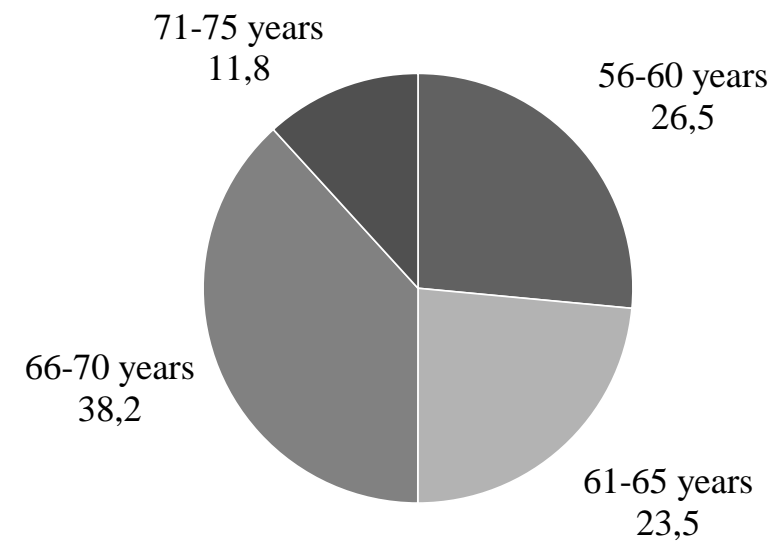

Figure 1 Distribution by age (\%)

The respondents were persons over 55 years of age, therefore, it is interesting to take note that most of respondents, who completed the questionnaire, were 66-70 year old persons (the oldest were 75 years of age, fig. 1). 70.6 percent were pensioners, 29.4 percent - not pensioners.

Duration of employment of most of respondents is over 30 years (38.2 percent), a significant percentage have been employed for over 20 years (26.5 percent, Fig. 2).

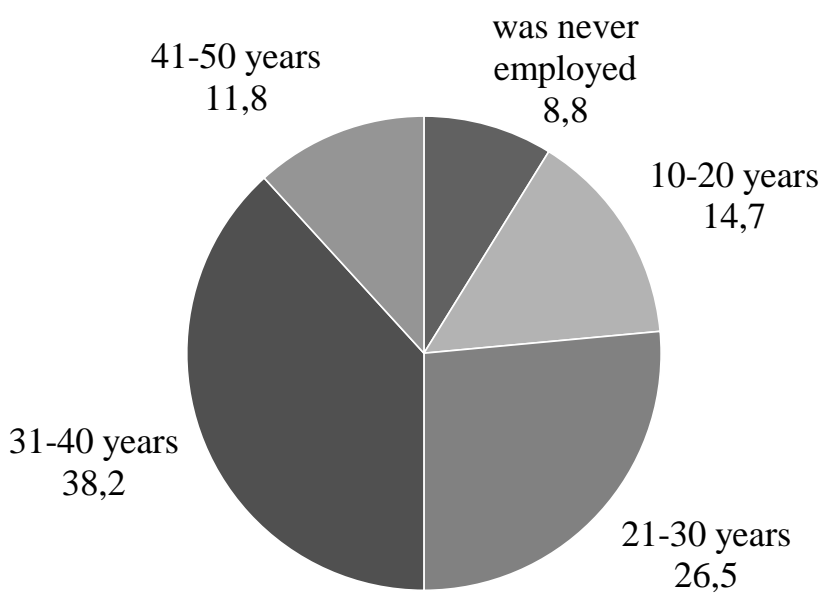

Figure 2 Distribution by duration of employment (\%)

Currently employed constitute 44.1 percent, unemployed - 50 percent, 5.9 percent did not answer. Two thirds have the university education, 2.9 percent of respondents have not acquired any profession. 
I use computer for other purposes than work

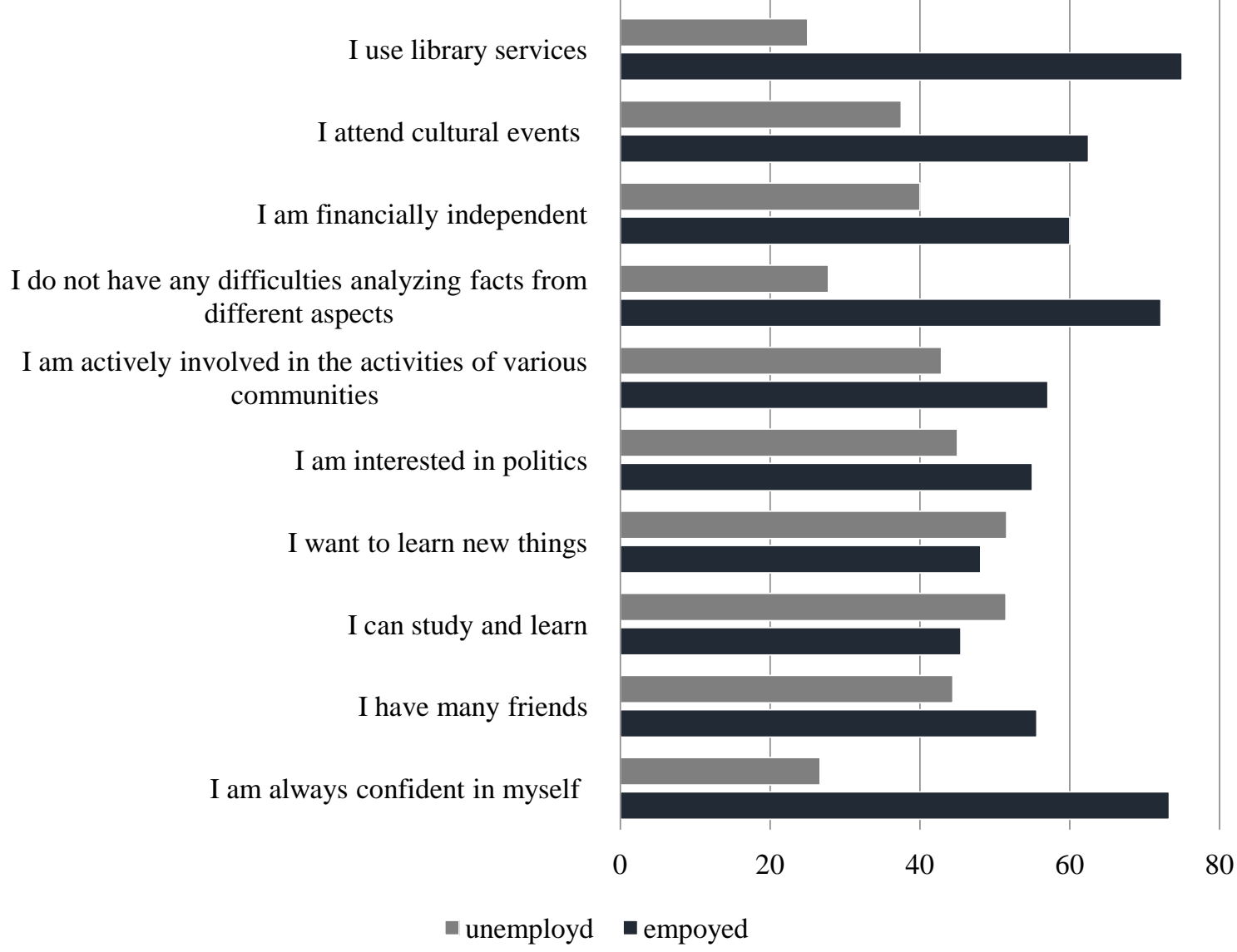

Figure 3 Assessment of emotional and social environment (\%)

Since the respondents are older persons, it is important to assess their emotional environment, social activity, and ability to adapt to the ever-changing environment. It is evident that in most cases currently employed persons are more adapted to changes (most of them have computer skills, are able to analyze facts, are more actively involved in the community activities, are more interested in politics), which gives them more self-confidence and guarantees a bigger circle of friends. However, the unemployed have not lost their wish and more often indicated that they would like to and could study new things. In all cases a statistically significant difference between the employed and the unemployed persons was identified (chi-square test $p<0,05$, Fig. 3 ).

Most of the unemployed are already of the retirement age and, therefore, are no longer employed. However, approximately fifty percent of respondents indicated that they were dismissed because of their age, for some of them their health is an obstacle. It is interesting to note that over 20 percent indicated that they do not care about work (Fig. 4). 


\section{I am underpaid \\ I cannot find job}

I was dismissed because the company went bankrupt

I was dismissed because of downsizing

I was dismissed because of my age
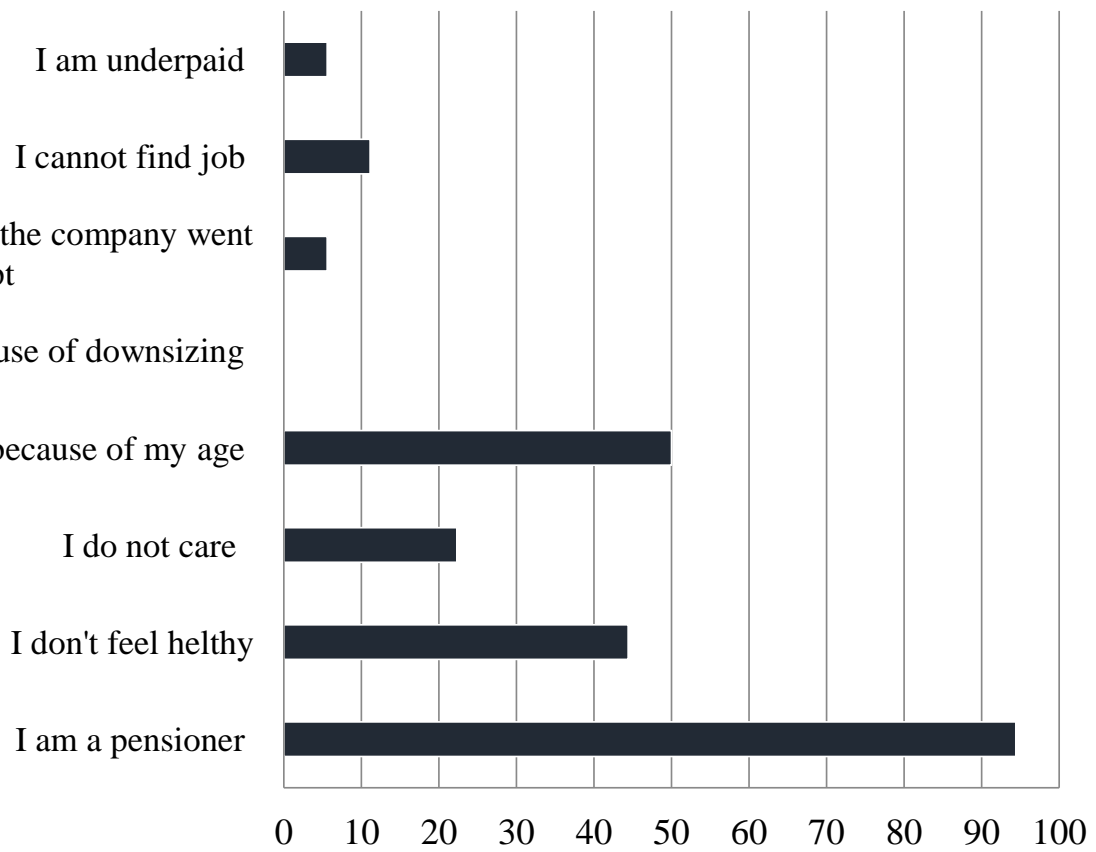

Figure 4 Reasons for not working (\%)

All persons in work indicated that they work because they like their professional activities and also for better financial opportunities. A significant percentage indicated going to work as a formed long-term habit. Approximately fifty percent of respondents indicated that going to work is a way for them to spend their free time or to "escape" from home environment (Fig. 5).

I like my professional activities

I want to have more means of subsistence

It is a way for me to spend my free time

I am used to it

It is a way for me to "escape" from home environment

I have ambitions in my career

I was asked by my employer
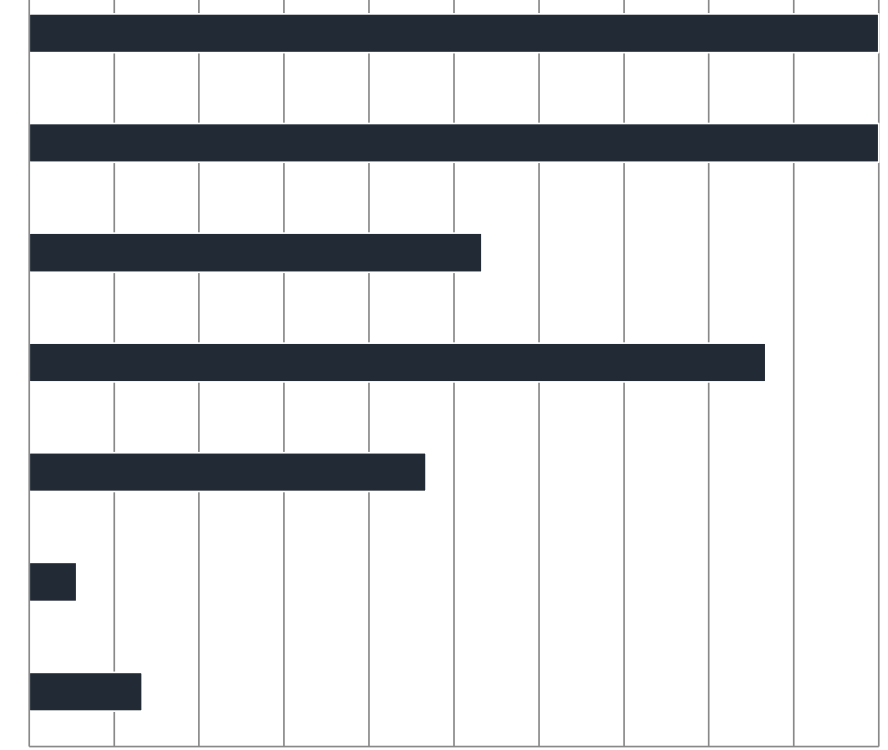

$\begin{array}{lllllllllll}0 & 10 & 20 & 30 & 40 & 50 & 60 & 70 & 80 & 90 & 100\end{array}$

Figure 5 Reasons for working $(\%)$ 
Proceedings of the International Scientific Conference. Volume IV, May $27^{\text {th }}-28^{\text {th }}, 2016.132-143$

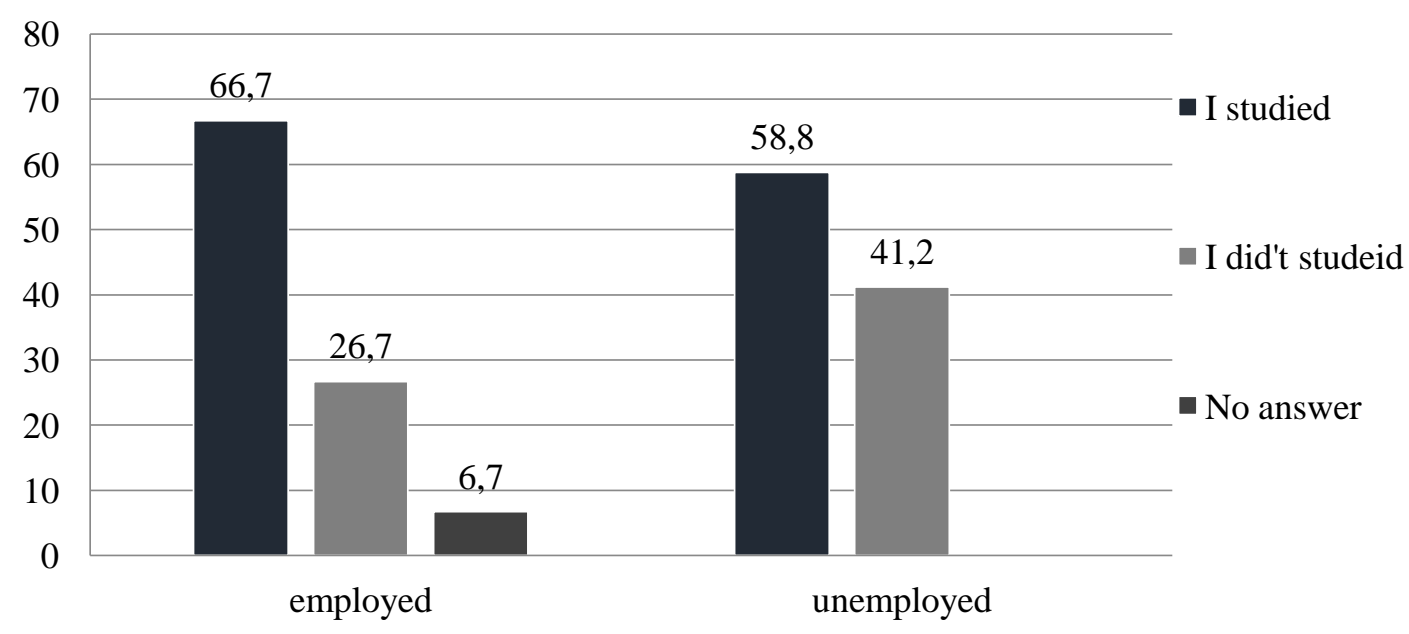

Figure 6 Studying over the last year (\%)

The majority of both employed and unemployed older people indicated that they have undergone studies, however, this percentage is slightly bigger among the persons in work (statistically no significant difference was identified, Fig. 6).

The reasons expressed by the employed and the unemployed why they study varied in most cases (Fig. 7). Persons in work often indicated that they were sent from the employment exchange, they need to acquire qualification and want to earn more. A significant percentage of the persons in work say they have discovered their vocation and, therefore, wanted to study some. Nonworking population also indicated that they studied (during their employment), because they were sent from the employment exchange, by the employer's instruction, or they needed it for the additional job. They wanted to study, because they used to like studying earlier; a favorable price was an important factor as well. However, the motivation for the persons in work to study is higher in most cases, though it is often related to their professional activities.

All persons in work, who currently do not study, state that now they do not have any need and do not see any sense of studying. However, over 90 percent (Fig. 8) stated that they lack information on training and confidence (more than non-working population) and it is hard for them to combine with their family. For non-working population it is the main reason for not studying. Also, one of the obstacles is high prices of training.

Following the completion of dependency analysis it was identified that persons with the university education are more willing to study (chi-square test $\mathrm{p}=0,044>0,05)$. 
I have a lot of free time

A very good price

A very convenient location

I want to learn to use the latest technologies

I feel better $(*)$

I used to like studying earlier

I needed it for my additional job

I was sent by the labour exchange $(*)$

So was instructed by my employer

My acquaintances have undergone studies (no differences)

I discovered my new vocation

This is a way for me to create

I want to improve

I want to change the environment

I want to find out more about health

I have to acquire qualification

I need to speak out $(*)$

I want to communicate

I want to earn more

I want to acquire new skills

I want to acquire knowledge
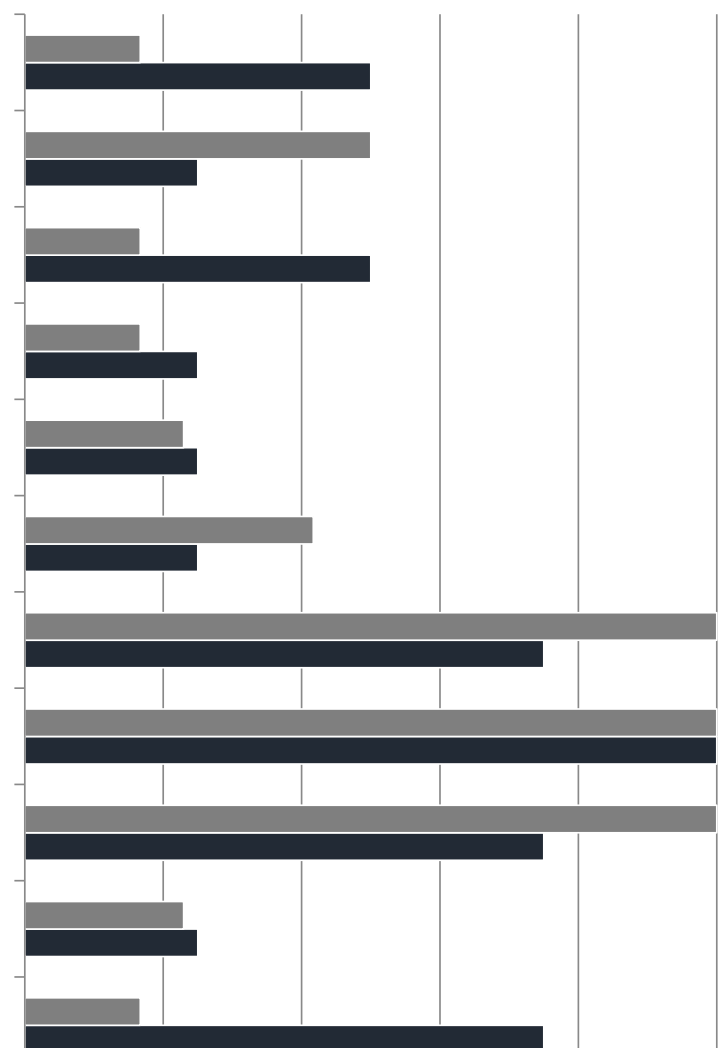

unemployed

- employed

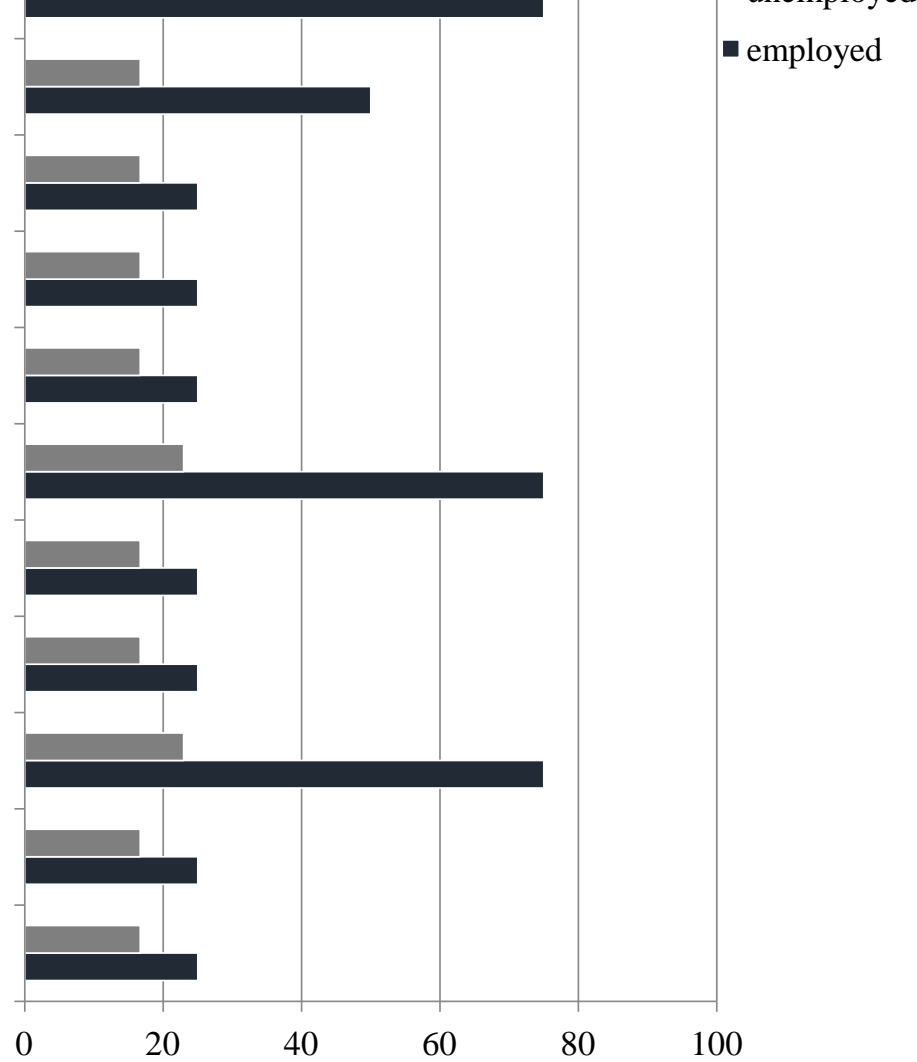

Figure 7 Reasons for studying (\%, * means "no significant differencies") 


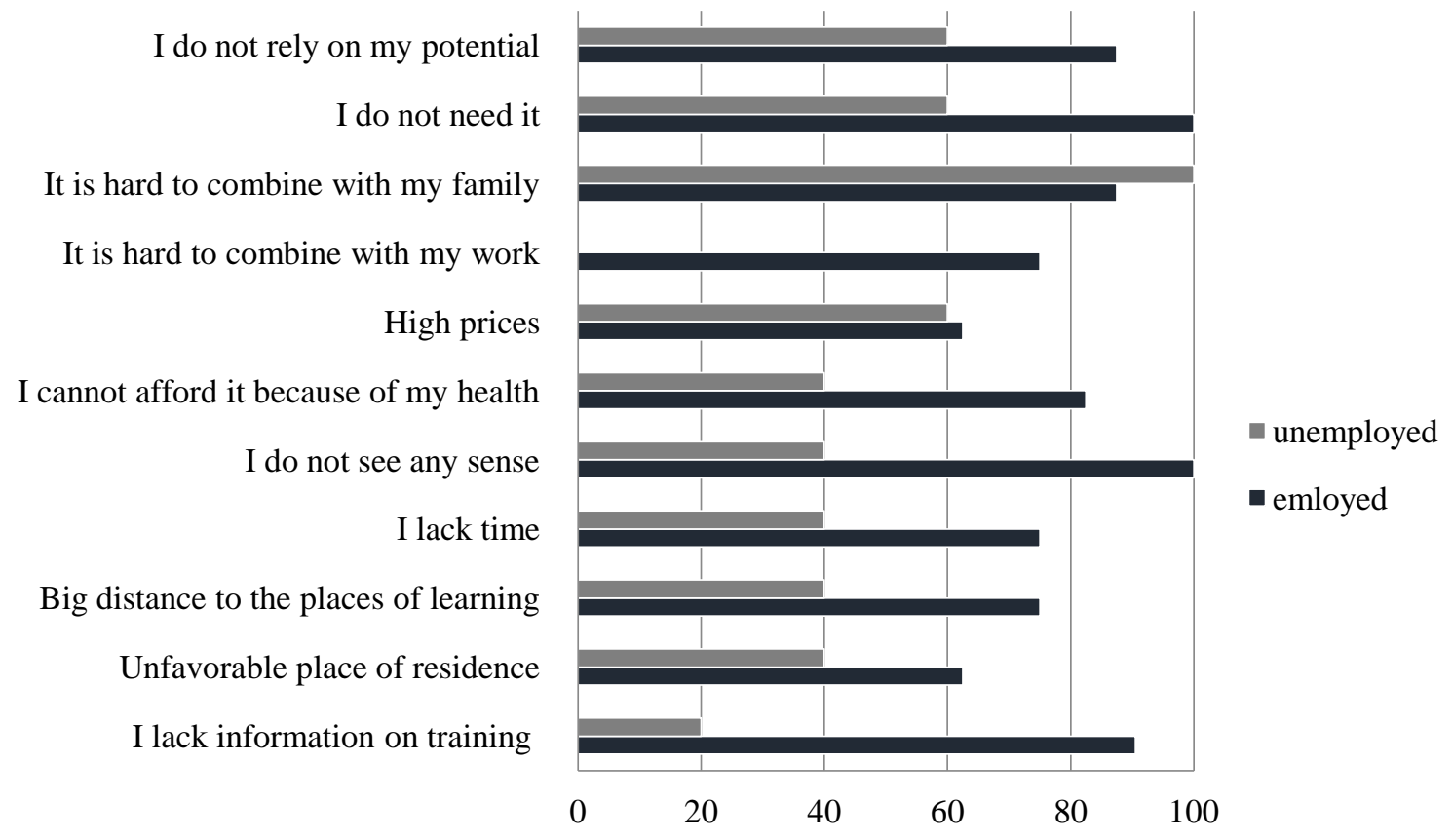

Figure 8 Reasons for not studying

\section{Conclusions}

External motivation factors are the ones to significantly encourage older persons to study and improve their professional as well as such other abilities and knowledge (especially clear understanding of the ever-changing and increasing requirements of the labour market), however, based on the analysis of scientific literature and surveys, we often see the internal factors prevailing as well: striving for improvement, broadening of horizons, self-realization, communication with other persons of similar age, and networking. Research results demonstrate that older persons, who are already employed, earn higher income, and have higher education, are the ones to study and improve their qualification in Lithuania more often, meanwhile persons, who are unemployed and earn lower income, as well as older persons, who live in rural localities, have relatively low motivation to study.

Quantitative research revealed that older persons in work are more adapted to the environment and technological changes, they are also more self-confident. Most of respondents are pensioners, who cannot successfully work because of their health problems or the fact that they were dismissed because of their age. Most of persons in work like their professional activities, which give them more financial resources. Both employed and unemployed persons are similarly willing to study. For the employed it is mostly related to their professional activities, whereas the unemployed are mostly sent from the employment 
exchange or need it for their additional work. The persons in work indicated both external and internal reasons as the obstacles. External reasons were more indicated among non-working population.

\section{References}

Barrett, A. \& Cantwell, L. (2007). Drawing on stereotypes: Using undergraduates' sketches of elders as a teaching tool. Educational Gerontology, 33, 327-348. doi: 10.1080/03601270701198950.

Beresnevičienè, D. (1996). Self-esteem and Interpersonal attractiveness among drop outs. International Journal of Psychology. 27 (3-4), 69-72.

Brazienė, R. et al. (2014). Vyresnio amžiaus žmonių (socialinės įtraukties) î(si)traukimo i darbo rinką galimybių tyrimo ataskaita. Vilnius: Lygiu galimybių kontrolieriaus tarnyba.

Butkienė, G., \& Kepalaite, A. (1996). Mokymasis ir asmenybès brendimas. Vilnius: Margi raštai.

Charness, N., \& Czaja, J. S. (2006). Older Worker Training: What We Know and Don't Know. Washington: AARP.

Dollisso, A. D., \& Martin, R. A. (1999). Perceptions regarding adult learners' motivation to participate in educational programs. Journal of Agricultural Education, 40 (4), 38-46.

Erikson, E. H. (1963). Childhood and Society. (2nd ed.). New York: Norton.

Eurobarometer. (2012). Active ageing. Special Eurobarometer 378 / Wave EB76.2 - TNS opinion \& social.

Ilmarinen, J. (2012). Promoting the Activity of Older People at the Workplace. European Agency for Safety and Health at Work. Internet access: https://osha.europa.eu/ 1t/publications/articles/promoting-active-ageing-in-the-workplace.

Juozulynas, A., Jurgelènas, A., Prapiestis, J., \& Butikis, M. (2010). Gyvenimo kokybès ir socialinių veiksnių tarpusavio ryšys. Gerontologija, 11 (1), p. 37-42.

Koncevičienė, N., Beržanskienė, M., \& Eidukaitienė, V. (2013). Vyresnių kaip 60 metų amžiaus žmonių laisvalaikio praleidimo galimybès Marijampolès savivaldybèje. Management Theory and Studies for Rural Business and Infrastructure Development, 35 (4), 554-563.

Mockus, A., \& Žukaitè, A. (2012). Sėkmingas senejjimas: psichologinis aspektas. Gerontologija, 13(4), 228-234.

Mokslinè studija: vertintoju - ekspertu veiklos poreikio analizè ir rengimo programa (2007). Internet access: http://www.vdu.lt/esf/esf0160/files/vertintojo-eksperto_1.pdf

Okunevičiūtė - Neverauskienè, L., \& Moskvina, J. (2007). Vyresnio amžiaus Lietuvos gyventoju profesinio mokymo ir konsultavimo poreikiai. Gerontologija, 8(4), 236-245.

Suaugusiuju švietimo raidos scenarijus. (2011). Lietuvos suaugusiuju švietimo asociacija, Internet access: http://www.smm.lt/uploads/documents/Veikla_strategija/scenarijai/ LSSA_scenarijus.pdf.

Sveiko senejjimo užtikrinimo Lietuvoje 2014-2023 m. veiksmu planas (2014). Internet access: https://www.e-tar.1t/portal/lt/legalAct/85fb0c200d7311e4adf3c8c5d7681e73

Tamutienè I. ir kt. (2009). Vyresnio amžiaus moteru ir vyru lankstaus darbo metodai ir praktinis taikymas. Vilnius. Internet access: http://www.sidmc.org/project_020/wpcontent/uploads/IV_vyresni_zmones_santrauka.pdf. 